\title{
Cutting Fluid
}

National Cancer Institute

\section{Source}

National Cancer Institute. Cutting Fluid. NCI Thesaurus. Code C122491.

Any fluid that is used for lubrication and cooling during metalworking and machining processes. They may be made from petroleum distillates, animal fats, plant oils, water, or other ing redients. Toxicity or irritation can result from contact with cutting fluids. The hazard can be the result of the fluid itself, the metal particles that are borne in the fluid, the bacterial or fungal contaminants that tend to grow in the fluid over time, the biocides that are added to inhibit those life forms, or the corrosion inhibitors that are added to protect the machine and tooling. 